Anders Ekenberg ${ }^{1}$

Newman Institute, Uppsala

\title{
The Church in Sweden. Secularisation and Ecumenism as Challenges
}

"Secularisation" is a concept that is used in many different ways. By secularisation one may, for example, mean a process through which the state ceases to legislate on the basis of religious faith and instead does so on the basis of what is commonly acknowledged. Or a process through which the state ceases to grant special privileges to religious bodies and stops supporting for instance religion-based education. Or a process meaning that people cease to hold religious beliefs and uphold religious practices. Or transfer of properties from religious or ecclesiastical to civil possession. Or a change meaning that society is no longer under the control of religion.

If secularisation means that a society frees itself from coercion or even tyranny of religion over the conscience of individuals, then secularisation must be valued positively from a Christian point of view. As the Second Vatican Council stated, this is a necessary consequence of the dignity of the human person:

1 Anders Ekenberg, anders.ekenberg@newman.se, Dr. of Theology, Docent (Uppsala University), formerly senior lecturer at Uppsala University, is professor of Theology at the Newman Institute in Uppsala, Sweden. The article is a lecture held at the Pontifical University of John Paul II, Krakow, 16 April 2015. The lecture format has been preserved. 
It is in accordance with their dignity as persons [...] that all men should be at once impelled by nature and also bound by a moral obligation to seek the truth, especially religious truth. They are also bound to adhere to the truth, once it is known, and to order their whole lives in accord with the demands of truth. However, men cannot discharge these obligations in a manner in keeping with their own nature unless they enjoy immunity from external coercion as well as psychological freed om. [...] [T] he right to this immunity continues to exist even in those who do not live up to their obligation of seeking the truth and adhering to it, and the exercise of this right is not to be impeded, provided that just public order be observed (Dignitatis humanae, n. 2, emphasis added).

Authentic faith can only be embraced by people who are free to say both yes and no, and manipulation of conscience as well as restraints of the right to follow one's own convictions always contravene the dignity of the human person - but also the spirit of the Gospel. "The truth cannot impose itself except by virtue of its own truth, as it makes its entrance into the mind at once quietly and with power" (Dignitatis humanae, n. 1).

However, secularisation may also imply that religion is regarded a purely private matter, a Privatsache without any social or political implications. Secularisation in this sense cannot be judged positively. On the contrary, humans must be free, not only to believe what they believe but also to give public expression to their faith, and hence to let faith influence society formation and public life. This is also a reasonable application of the Universal Declaration on Human Rights:

Everyone has the right to freedom of thought, conscience and religion; this right includes freedom to change his religion or belief, and freedom, either alone or in community with others and in public or private, to manifest his religion or belief in teaching, practice, worship and observance (United Nations, Universal Declaration on Human Rights, art. 18).

In my own country, Sweden, there is since a couple of years an ongoing public debate on what a "secular" state and society might or should mean. Some claim that Sweden is not secular enough as long as religious bodies are supported by the state through public grants, as long as these are permitted to use state tax resources to collect their membership fees, as long as public service radio and television send programmes like worship services, as long as religious weddings are publicly recognised, as long as religious bodies are permitted to count children as members, etc. Others 
claim that a clear distinction must be made between a secular st a te and a secular society. The state, they say, should indeed be neutral in its attitude to various religions and worldviews, but society is quite another matter: society is the sum of the population and the various religious and other preferences characterising the population, and to try to make society secular is identical to suppressing religion.

\section{A thoroughly secularised country}

Almost regardless of how one defines secularisation - on the level of society/state, of organisations, or of individuals - it is a generally accepted fact that present-day Scandinavia is one of the most secularised regions of the world, and my own country, Sweden, counts with Japan as the most non-religious on the globe. According to the most recent World Values Survey study, almost 60 percents of the Swedes never take part in a worship service, and only a tiny minority (some 3 percents) are weekly churchgoers. Other sources confirm this picture. ${ }^{2}$

Sweden is, accordingly, one of the countries in the world where religious faith and practice count least. It would be an unexpected miracle if this would change in the foreseeable future. The majority of the population simply do not acknowledge religion or religious life any longer, though 40 percents say that they believe there is a God in some sense or another (mostly not in a theistic sense). Most Swedes consider religion to be unnecessary; for them, it has ceased to be a factor to reckon with when it comes to everyday life, moral choices, societal planning, education etc. Few indeed pray regularly, though not so few as those who are regular participants in worship services.

of course, this does not mean that there is no religious life in the country or that there are no vibrant Christian congregations in it; there

\footnotetext{
2 A brief overview in English of the findings and insights of the most recent World Values Survey study (2011) is found at http://www.worldvaluessurvey.org/WVSContents. jsp?CMSID=Findings (10.04.2015). Cf. also the material on Sweden at Eurel:Données sociologiques et juridiques sur la religion en Europe, http://www.eurel.info/spip.php?rubrique66\&lang=fr (10.04.2015).
} 
really are. Neither does it mean that people in general are hostile to religion. Sceptical and estranged - yes, but hostile - rather seldom. Neither does it mean that religion is completely absent from the public arena. Religious issues are - even more now than, say, twenty years ago - now and then discussed in public. In situations of crisis people ask for the assistance of the churches, and there is perhaps an even increased tendency to trust them in such circumstances. The absolute majority of the population has, however, ceased to count religion as anything important. Estrangement and indifference are words which seem to capture the situation correctly.

Western and northern Europe, where strong secular trends characterise societal changes and public life, is not representative for the world in its entirety. For instance, British sociologist Grace Davie has with very good reasons spoken of Europe as an "exception" when it comes to religious commitment and practice. ${ }^{3}$ And if Europe with its generally low rate of religious commitment and practice is an exception, Sweden is one of the most exceptional countries of all. It is, consequently, a fact that Swedish Christians and churches are at the forefront of what it means to live in a thoroughly secularised society - though the churches and their leaders are not, perhaps, always quite aware of this fact and of what it requires.

I will come back to the question how the churches respond to this situation of radical diaspora. It may, however, be useful to start with sketching briefly the historical background.

\section{History}

Christianity reached Sweden in the Middle Ages. The first known missionary, Saint Ansgar, arrived in Sweden already in 829, but his activities did not leave many traces. The church did not really begin to take root in the country until in the $11^{\text {th }}$ century, then not least through the

3 G. Davie, Europe: the exceptional case: parameters of faith in the modern world, London 2002; cf. G. Davie, Religion in modern Europe: a memory mutates, Oxford 2000. 
efforts of monk-missionaries from the British Isles. The first king to remain a Christian until his death was baptised around the year 1000.

The church in the country soon came under German influence. The dioceses erected from the $11^{\text {th }}$ century and onwards were initially part of the church province of Hamburg-Bremen. In 1164 Sweden was made a church province with an archbishop in Uppsala, though at the beginning under the supervision of the head of the Danish church, the archbishop of Lund, who, in turn, was dependent on ecclesiastical authorities in Germany. (Southern Sweden remained Danish until the $17^{\text {th }}$ century.)

Church life in Sweden seems to have flourished in the later Middle Ages. St Bridget of Vadstena (now patron of Europe) erected a "double" monastery with both monks and nuns there in 1384. During the entire $15^{\text {th }}$ century Vadstena was an enormously influential spiritual centre, and there are other clear signs that the church was really flourishing during the $15^{\text {th }}$ century. The situation was also, however, characterised by power struggles between bishops and nobility, fights which were partly caused by the fact that the bishops were not only ecclesiastical leaders but also political and even military rulers.

According to the standard picture transmitted in Sweden after the $16^{\text {th }}$ century, the late medieval church would have been as corrupt and marked by superstition as important parts of the church in German countries appear to have been; this would explain the necessity and success of the Lutheran reformation in Sweden. This picture does not, however, seem to be quite accurate. True, not only Lutheran but also modern Catholic historians have tended to confirm that the church in Germany was really in need of deepgoing reform at the beginning of the $16^{\text {th }}$ century. It cannot, however, be taken for granted that this was to the same extent true in other regions, as for instance Scandinavia. On the other hand, the cries for reform were indeed widespread throughout Europe in the $15^{\text {th }}$ and early $16^{\text {th }}$ centuries, and it is difficult to believe that the church in Scandinavia would have been a complete exception, a church not in need of any reform whatsoever. Hence, one should probably not paint an altogether idyllic picture of church life in, for example, Sweden of the $15^{\text {th }}$ century. On the other hand, the state of affairs in the church 
in this period is not the most important explanation for the Lutheran reformation in Sweden. Politics, on the other hand, is.

True, the king of Sweden from 1521 to 1560, Gustav Vasa, and his advisers came under the influence of the Lutheran reformers, and this had as a consequence that the national church was to proclaim itself to be Lutheran. But the reformation in Sweden most of all had a political and financial background. The new king, crowned in 1523, had the ambition to make Sweden an autonomous country under a strong centralised leadership; and he thought he needed the financial means controlled by the bishops and owned by the monasteries in order to obtain this. Consequently, in a way partly reminding of the English reformation, the king made himself supreme of the church, which meant that he denied the supremacy of the pope but also the validity of canon law as law of the national church. The supremacy of the king was to continue until relatively recently. On the other hand, the transformation of the national church into a Lutheran church - the transformation of doctrine, worship and everyday Christian practice in accordance with the ideas of the Lutheran reformers - was not completed until toward the end of the $16^{\text {th }}$ century. In 1593 the church of Sweden formally adopted the Lutheran confession as binding for itself and, thereby, for all inhabitants in the country. (This in practice made the situation of the newly appointed king at the time, the Catholic Sigismund, grandson of Gustav Vasa and king of Poland since 1587, very difficult. He was removed and ejected from the country a few years after, in 1599.)

As a consequence of the supremacy of the king and of the adherence of the church to Lutheranism, being a Lutheran was made strictly compulsory for all citizens. Unlike other Lutheran churches, the church in Sweden preserved a number of forms and institutions from the medieval church that were abolished elsewhere, for example the office of bishops, and one continued speaking of the ministers as "priests" and of the most important form of worship as the "Mass". Neither the ministries nor the Mass were, however, understood as before. The Mass was reshaped in accordance with Lutheran theology. For a certain period during the $17^{\text {th }}$ and $18^{\text {th }}$ centuries two forms of ecclesiastical leadership even existed in parallel: bishops in the old dioceses and "superintendents" in the 
newly erected ones. This demonstrates the fact that the apostolic ministry as conceived of earlier had not been preserved. But the new structures were also a way of strengthening the king's leadership in the church and his power in ecclesiastical matters.

Being a practising member of the Lutheran national church was after 1593 strictly compulsory for all Swedes. Religious practice was severely controlled, not least during the $17^{\text {th }}$ century and until Enlightenment ideas began to take root. No freedom of religion existed, though Calvinist immigrants were tolerated, not least because of their importance for the development of industry and commerce. Starting in the 1770s the king granted permission to immigrants to practice their religion; this among other things meant that Catholic worship was once again permitted - but not for Swedish citizens. ${ }^{4}$ During the $19^{\text {th }}$ century the emergence of new religious movements under inspiration from England (Methodists; Baptists) in combination with the influx of liberal ideas gradually undermined the "unity in religion" in the country. From 1858 religious gatherings not lead by a priest were permitted (they had been prohibited by law since 1723), and through laws of 1860/73 members of the national church were permitted to leave it if they entered another recognised Christian denomination. However, religious freedom in the sense of freedom not to belong to any denomination at all was not granted until in 1951.

The church of Sweden after 1527 was and remained a state church: an official body ultimately governed by the king (or the government) and part of the state. In the middle of the $19^{\text {th }}$ century a "Church Synod" or "Church Assembly" (kyrkomöte) was created: a decision-making body consisting of representatives of clerics and laity. However, the decisions of the synod had to be confirmed by the parliament or the government. The lack of independence of the synod is well illustrated by what happened still in the 1950s. The synod of 1957 said no to the government proposal that the church should permit women to be ordained

4 In a certain sense, the history of the diocese of Stockholm, comprising the entire country, started in 1783, when Abbé Nicolaus Oster was made an apostolic vicar. The diocese as such was erected in 1953. The present bishop (since 1998), Anders Arborelius OCD, is the first native Catholic bishop in the country since the reformation. 
and decided to investigate the question further. The government, however, ordered the convocation of an extraordinary session of the synod already the year after and let the synod understand that a renewed "no" would not be accepted. The synod agreed to the ordination of women. The conflicts surrounding this decision are still felt, the wounds have not yet healed, but the parts of the church saying "no" have been progressively marginalised.

During the $19^{\text {th }}$ and $20^{\text {th }}$ centuries other Christian bodies have gradually developed and gained importance. As mentioned above, new Protestant movements have arisen; the most important of them, in terms of numbers of adherents, are today the Pentecostals and the so-called Equmenia Church (a denomination of a general Protestant character, a union of three formerly separate free churches). In total, some 300000 people belong to these "free churches", as they are normally called (originally in contrast to the established church.) The Catholic church has also grown, especially after the 1960s and mainly through immigration. Today, approximately $3 / 4$ of the Catholics are immigrants or children of immigrants. The numerically most important groups are Poles, Croats and Latin Americans, but there are also a significant number of Oriental Catholics, especially Chaldeans. Because the immigration authorities are forbidden by law to ask immigrants of their religious adherence, nobody really knows how many Catholics there are in the country, but there were in $2014 \mathrm{ca} .110000$ registered members of the church, and the total number is normally estimated to ca. 150 000. Immigration during the last decades has also, however, contributed to a growing Orthodox presence in the country, especially of Oriental Orthodox Christians. ${ }^{5}$ The total number of Eastern and Oriental Orthodox Christians more or less equates the number of Catholics. A clear sign of what the situation looks like now is how the Christian Council of Sweden is organ-

5 Similarly, the number of Muslims in Sweden has grown considerably during the last decades. Only ca. 120000 of them are registered members of the communities receiving public grants through the so-called Islamic Cooperation Council, but the estimated total number is $400-500000$, most of them Sunni. Because of immigration, especially of refugees from the Middle East, the Muslim population will probably rise considerably in the next few years. 
ised. The denominations represented in it are divided into four "families": Lutheran, Catholic, Orthodox (both Oriental and Byzantine) and free churches.

However, the growth of the Protestant free churches and of the Catholic and Orthodox churches does not alter the fact that the Church of Sweden, to use its official name, is the dominant Christian body in terms of numbers. In the year 2000 the relationship between the state and the Church of Sweden was changed: the church became formally free to take its own decisions, the bishops ceased to be appointed by the government, and a lot of other changes were introduced. However, this did not mean complete disestablishment. Since 2000 a civil law adopted by the parliament in 1998, "The Church of Sweden Act", governs the existence and work of the church. This law states that it is (and has to be) an Evangelical-Lutheran church, organised in accordance with democratic principles and active everywhere in the country. The church is in this civil law defined as a folkkyrka, i.e. a "Folk Church". What this means in practice will be discussed below.

Today, some 65 percents of the population formally belong to the Church of Sweden, meaning that it has ca. 6.3 million members. The other Christian denominations have roughly 600000 members taken together. The number of members of the Church of Sweden is, however, quickly decreasing, and it will probably have obtained a minority status - comprising less than half of the population - in less than ten years.

There is also, however, a considerable difference between the different denominations as to what it means to be a member. Among the 6.3 million members of the Church of Sweden, not more than ca. 1.3 percents (ca. 83 000) take part in the main worship service on Sundays on a weekly basis. (Ca. 300000 are going to church at least once or a couple of times a month). Ca. 300000 or perhaps even a little more is a reasonable estimate of the number of weekly churchgoers in the other denominations taken together. The free churches have a very strong tradition of active membership; being a member also means taking an active part in the life of the congregation, going to church regularly, putting one's forces and money at the disposal of one's church, etc. Orthodox and Catholics are less active, but considerably more than 
the members of the national church; one can realistically guess that at least some 25-30 percents of the Catholics and Orthodox are reasonably regular churchgoers. ${ }^{6}$

In other words, the discrepancy between formal membership of the church and real faith and practice is far greater in the case of the Church of Sweden than in the other denominations in the country, but also in comparison to most other churches or denominations worldwide. The decrease of Swedes participating in the life of the church and sharing its faith is to a large extent a $19^{\text {th }}$ and $20^{\text {th }}$ century phenomenon: through the influx of new ways of conceiving reality and new ways of looking at religion and religious obligations, through deepgoing social change and urbanisation without corresponding deepgoing renewal of church structures, and for a number of other reasons, the vast majority of Swedes gradually ceased to be consciously Christian and ceased counting religion as important. From being a monolithical society governed by the idea of unity in religion Sweden developed into a pluralistic country, where people choose which convictions to adhere to, and where religion and church ceased to be of any significant importance for most of them. Earlier, the officials of the church were not only religious leaders but also state officials, obliged to watch over the inhabitants of the country; the priests were, so to speak, in a position comparable to the police. As a consequence of the liberal and democratic breakthroughs during the $19^{\text {th }}$ century and onwards the majority of the people has let go of letting the church govern their lives. In other words, secularisation partly has meant a liberation from restraint or authoritarian pressure.

On the other hand, this has not meant that people have in masses joined the Protestant free churches, though these were, especially during the $19^{\text {th }}$ century, important drivers of individual freedom. Reasons for this are partly the traditional ethos of these free churches and their

6 There is an unfortunate lack of detailed statistics and of sociological studies going deep enough when it comes to the Catholic and Orthodox churches in Sweden (and Scandinavia at large). This lack of solid knowledge is a serious deficit, making much of the pastoral work of the churches rely on pure guesswork, and is also an impediment for the integration of different ethnical groups. 
teachings: they were largely considered to be anti-intellectual and anti-rational, and the strong group coherence among free church Christians was repelling to many, as was their puritan ethics. The free churches are still minority denominations and will undoubtedly remain so, perhaps even decrease.

Neither is there a strong tendency to convert to Catholicism or Orthodoxy. The yearly number of Orthodox converts is not known, but they are few indeed. And though the Catholic church is today rather visible on the public arena, and many of the inherited anti-Catholic resentments are more or less gone, the yearly number of converts to the Catholic church seldom exceeds 100. Add to this the number of adult baptisms (including adolescents baptised before confirmation), and you get a total yearly sum of ca. 100-150. There are no signs of increase in these numbers.

Because of the historically very strong position of the national church in the country, and because the other denominations are small, speaking of 'secularisation" in Sweden not least means speaking about what has happened to the role of the national church. Consequently, the questions of strategy for the future are not least questions that should be addressed to the Church of Sweden. All Christian denominations in the country should, of course, spend much energy on trying to discern together how to face increased secularisation and how to give as strong a witness as possible. But the church that should feel most "threatened" by the continual decrease in religious commitment and practice is the biggest player, so to speak: the Church of Sweden.

\section{The strategy of the national church}

There is an obvious inherent temptation in every discussion of secularisation to overestimate religious commitment and practice of people in past times. As for example French historian Jean Delumeau has repeatedly stressed, ${ }^{7}$ one has to make a clear distinction between Christianity as

7 J. Delumeau, Le christianisme va-t-il mourir?, Paris 1977; J. Delumeau, Un chemin d'histoire: Chrétienté et christianisme, Paris 1981. 
really adhered to and put into practice, and Christianity as an institutional form. It would be illusory to depict, say, the late Middle Ages or the early modern period as time periods when all citizens embraced faith from within and Christian practice was always founded in sincere convictions. When it comes to Lutheran Sweden, already the repeated emergence of revival movements within the national church, from the late $17^{\text {th }}$ century and onwards - movements stressing the necessity of personal commitment in faith - demonstrates the lack of such commitment in wide circles. However, a minimal amount of Christian practice was compulsory and was virtually always there. Every form of education was religion-based. Everybody was expected to think and act as a Christian. Everyone was baptised, and Christianity surrounded people and influenced their lives from the cradle to the grave. As a consequence of recent developments the situation is now completely different.

In spite of this, the Church of Sweden is still not completely disestablished and does not seem to want to stand completely on its own feet. The ideological basis for this and for its strategy when it comes to facing increasing secularisation has for most of the $20^{\text {th }}$ century been the ideology of the Folk Chu r ch. This term, which started being used on a wider scale in the early $20^{\text {th }}$ century, has taken on different shades of meaning. Let me just mention the two most important of them.

The early ideology of the Folk Church, as propagated by influential church leaders of the 1920s and later, meant that the church should understand itself as a church for the entire people - a church including everybody and having the mission to reach out to everybody in the country by means of the Word of God and the sacraments (especially infant baptism). The early propagators of this ideal, for instance Bishop Einar Billing (1871-1939), were convinced Lutherans. They supported the existing establishment of the church, but at least some of them were of the opinion that a collision between the values adhered to by the church and values propagated by the state was theoretically possible. In such a situation, should it occur, it would no longer be possible for the national church to live in a symbiosis with the state. It would not, they said, be possible to accept an interference of the state in ecclesiastical matters if this would mean that the church would be forced to dis- 
obey the Word of God. On the other hand, they did not seriously count with such situations.

A similar way of thinking, though much further developed, still governs most of the strategy and planning of the congregations and dioceses in the Church of Sweden. Great stress is put on infant baptism as an expression of God's generosity toward all human beings, and one normally also lays great stress on the idea that God in his love toward humans does not really require anything of them, perhaps not even belief. The church must, it is often said, let the doorsteps into it remain as low as possible; one must never let anybody feel excluded, all are welcome. An often-repeated slogan has been "Come as you are!" The necessity of conversion is seldom mentioned, at least by mainstream representatives of the church. For some decades after World War II there was an active movement in the church, stressing the need to build vibrant communities based on committed lay people; this in turn presupposed that an important task of the priests would be to stay in close contact with such people, helping them to deepen their faith and commitment. Such a pastoral strategy is today often regarded as "elitist". It is said in an official printed presentation of the Church of Sweden, A Room for Everybody, aiming at inviting people to become members:

Faith is something deeply personal which cannot be weighed, measured or judged. Sometimes it is easy to believe, sometimes very difficult. The Church of Sweden is there both for those who believe, for those who are seekers and for those who doubt. Regardless of your attitude toward God, you are welcome to share your joy and your sorrows, your visions and your uncertainty. In the Church of Sweden there is room and context where you are allowed to ask questions and propose answers. We talk with one another about life and the faith. ${ }^{8}$

The church as a "room" where everybody should feel at home and where one "talks with one another about life and the faith" - this open and all-embracing attitude is the national church's governing strategy in confronting secularisation. Of course, this means that one has opted

8 Rum för alla: Lite mer om Svenska kyrkan [A Room for Everybody: A Little More about the Church of Sweden] http://issuu.com/svenskakyrkan/docs/rum_f_r_alla_lite_mer_om_sven ska_/1 (10.04.2015). The quotation is found there on p. 2. 
for a highly institutional ecclesiology: the church is rather an institution offering possibilities of reflecting over one's life and of coping with difficulties than a community of faith. Similarly, the demands on the ministers of the church when it comes to identifying themselves with the traditional doctrine of the church have been drastically reduced.

I have tried to clarify one of the meanings of the term "Folk Church" and to describe briefly some strategical consequences of it. There is, however, also another meaning of the term that must be mentioned. This second meaning is political.

The proponents of the ideology of the Folk Church stressed, as we have seen, that the church is to be a church for all, open to all. However, the same notion was also from rather early on - to start with by politicians, later also by theologians - understood as meaning that the church is to be governed by the people. Politicians in the 1930s and 1940s started maintaining that the governance of the church had to be transformed, so as to be fully democratic. In the 1950s and 1960s this idea was picked up by some influential theologians as well. The church, one argued, must be anxious to involve the entire people, and this requires that the people is also allowed to decide on church matters on all levels, practical as well as theological. Elections to local parish councils as well as the national synod (and on levels in between) of course presuppose that people are nominated; somebody has to put forward suitable candidates for election. Here, the political parties became involved as nominating bodies. As a result, most members of the decision-making bodies on all levels have a place in them, not because of their religious commitment or importance in church life, but as representatives of the respective political parties.

The foundations of this system were laid already in the second half of the $20^{\text {th }}$ century. However, it has also survived the disestablishment in the year 2000. True, there are also some other nominating bodies, active both on the local and the national level and in between: bodies calling themselves for example "The Politically Independent" or "The Outspoken Church". But the majority of members of decision-making bodies are there because they have been nominated by the political parties, and people have elected them on the basis of these nominations. 
This facet of the ideology of the Folk Church probably makes the Church of Sweden quite unique, and of course there is a danger built into the system: a danger that the church as a religious body will be prevented to act on its own beliefs. This, in turn, affects the ministers of the church. The values upheld by representatives of the church on the public arena - including numerous priests - are nowadays very similar to public opinion or to the values upheld by the political parties. Of course, this has created severe controversies within the church; many have protested against what they consider to be too far-reaching accommodations to public opinion or to the priorities of, e.g., the parties and the media.

In November and December 1999, just before the disestablishment, Polish-born Maciej Zaremba, one of the most respected journalists in Sweden, published a series of articles in the leading newspaper "Dagens Nyheter" ("News of the Day") analysing the consequences of the changes that would take place as by 1 January $2000 .{ }^{9}$ He started the series by saying:

When the church at the turn of the millennium is separated from the state, this is an historic event. But the question is whether the most decisive thing has not already happened: in the evening of 10 June the bishops were [by the national synod] denied the right to vote in dogmatic matters. The power of politicians over the church will from now on, as a matter of fact, be stronger than ever before. [...] The new Church of Sweden will be a unique contribution to the history of religion: the first independent denomination in the world where the bishops lack the right to vote in matters concerning faith, and where the meaning of Christianity is determined by political parties.

In fact, the system of having a national synod where the bishops are not permitted even to vote in matters of faith was changed in 2009; now the bishops have a strengthened position when it comes to the Synod's dealing with doctrinal issues. This does not, however, change the fact: the power to decide on the innermost matters of the church has large-

9 The articles were published in Dagens Nyheter in November-December 1999 and were later collected and published in Maciej Zaremba, Kyrkan \& friheten [The Church and Freedom], Gothenburg 2000. The translations in the following are mine. 
ly been transmitted from the church's own bearers of religious tradition to people mostly sitting on a political mandate. Some of them share the church's faith, others do not. Zaremba continued:

The great event of New Year's night is therefore not that the Church of Sweden is separated from the state. The most important thing is instead that the church becomes still more politicised, i.e. that it becomes secularised almost over the verge where one can still speak of a church. [...]

One may say that the extraordinary continuity of Christian tradition is upheld by three connections. First, the spiritual heritage taken over from the Apostles and transmitted by their successors. It is neither the emperor nor parliaments or other publicly elected people but those who have devoted their lives to the church who carry the main responsibility for interpreting, explaining and transmitting the message. Even if laity have, throughout history, played an important role in the history of religion, faith is ultimately nothing you invent by democratic decision; it is instead something towards which one takes a stand.

The second connection is the connection between priests and their bishop in his capacity of their leader and carer of souls. The third, finally, is the connection between the individual congregation and the church at large. If you are to believe literally what is said in the new Constitution of the Church of Sweden, not much of these three connections is left after New Year's night.

From now on, the priests are no longer subordinated to the bishops. They have become "civil servants" employed by local, mostly politically elected parish councils. In other words, they are from now on employees on a market and no longer, as earlier, part of a diocesan structure. After 1 January, no bishop seeing that the parish in X or Y would profit from having a vigorous vicar will any longer be able to send them his best priest. The parish in X can, however, choose to employ the priest they find most loyal to their convictions.

The ideology of the Folk Church had perhaps, in its faith-based version, a certain plausibility as long as the people was eager to maintain a certain amount of Christian practice. However, it is sufficient to study statistics to convince oneself that this is more and more seldom the case. Official Church of Sweden statistics shows a drastic decrease as to the number of baptisms, confirmations etc. - the very basis of the first-mentioned, faith-based version of the ideology of the Folk Church. ${ }^{10}$ The

10 See: http://www.svenskakyrkan.se/default.aspx?id=1132666\&ptid=48063 (7.04.2015); and the website Svenska kyrkan i siffror [The Church of Sweden in Figures] http://www.svenskakyrkan.se/statistik (7.04.2015). The material is there presented in Swedish. 
figures (percents of the total population, except in the case of participation in principal services on Sundays) probably speak for themselves:

\begin{tabular}{|l|c|c|c|c|c|}
\hline & 1970 & 1990 & 2010 & 2013 & TOTAL \\
\hline Baptisms & $80.6 \%$ & $71.1 \%$ & $53.7 \%$ & $48.5 \%$ & $-32.1 \%$ \\
\hline Confirmations & $80.7 \%$ & $63.4 \%$ & $41.0 \%$ & $30.1 \%$ & $-50.6 \%$ \\
\hline Weddings & $79.3 \%$ & $64.0 \%$ & $36.6 \%$ & $33.9 \%$ & $-45.4 \%$ \\
\hline Funerals & $95.5 \%$ & $93.3 \%$ & $80.9 \%$ & $78.0 \%$ & $-17.5 \%$ \\
\hline Membership & $97.5 \%$ & $88.4 \%$ & $83.0 \%$ & $66.0 \%$ & $-31.5 \%$ \\
\hline $\begin{array}{l}\text { Participants } \\
\text { Sunday services }\end{array}$ & & 9 millions & $\begin{array}{r}2000: \\
6.6 \text { millions }\end{array}$ & 4.32 millions & $-52.27 \%$ \\
\hline
\end{tabular}

What remains relatively steady is only funerals. The decrease that has taken place when it comes to the average number members participating weekly in the main worship services on Sundays (Eucharist or Liturgy of the Word) is the most dramatic of all: ${ }^{11}$

\begin{tabular}{|l|c|c|c|c|c|}
\hline & 1990 & 2000 & 2010 & 2013 & TOTAL \\
\hline $\begin{array}{l}\text { Participants } \\
\text { Sunday services }\end{array}$ & 9.05 millions & 6.63 millions & 4.61 millions & 4.32 millions & $-52.27 \%$ \\
\hline Weekly participants & 174038 & 127500 & 88712 & 83096 & \\
\hline
\end{tabular}

11 Many other forms of worship service than the Mass or the Liturgy of the word are held. Some of these can, when taking place on Sundays, be considered replacements for these principal services. The total number of participants in services excl. baptism, weddings, confirmations and funerals was in $1990 \mathrm{ca} .18$ millions, in $2000 \mathrm{ca} .15 .4$ millions, in 2010 ca. 11.5 millions, and in 2013 ca. 10.2 millions. In these numbers are not only Sunday services but also services on weekdays, concerts with a certain worship aspect etc., included. The total decrease from 1990 to 2013 was here 43,33 percent. 
The only possible conclusion is that the strategies built on the ideology of the Folk Church, as it has been understood by the leaders of the Church of Sweden, have completely failed. Except for the assistance of the church at funerals there is no plausibility to this talk of the Folk Church any longer. There are, however, very few signs indeed that this ideology will be given up, at least in the foreseeable future.

\section{Ecumenism}

Because of the historically given important position of the Church of Sweden, every consideration or planning when it comes to efforts to transmit the Gospel in Sweden, every strategy as to how to encounter fruitfully the situation of deepgoing secularisation, must, in order to be meaningful, somehow count with the national church. On the other hand, its deep convictions of the blessings of the Folk Church - in the senses I have described - effectively block ecumenical conversations on how to join efforts to transmit the Gospel in the country. The other denominations of course cannot even think in the categories that have since a long time dominated the national church's thinking on how to transmit and present Christianity.

However, the close and not easily described alliance or alloy of the national church and public opinion has other ecumenical implications as well. On the one hand, the ecumenical climate has changed considerably for the better during the past fifty years, not only between the national church and the free churches, but between all denominations. The relations are far more friendly than they used to be. Many fruitful ecumenical initiatives have been taken, and there are solid ecumenical institutions in the country. Probably still more important is the fact that "spiritual ecumenism" has developed considerably during the last decades. And in many ways the different churches now resemble each other more than earlier, for example when it comes to the exterior forms of worship. Some inherited doctrinal differences do not seem to be nearly as important now as they used to be. 
On the other hand, there are nowadays considerable differences when it comes to the goals of ecumenism. For Catholics and Orthodox, the goal of all ecumenical efforts is visible unity: unity in faith, sacraments, church governance, witness and service, i.e. "full ecclesiastical communion". For certain groups within the national church as well as the free churches this also remains the goal of ecumenism - that goal which the World Council of Churches embraced in its 1961 New Delhi Statement on Unity:

We believe that the unity which is both God's will and his gift to his Church is being made visible as all in each place who are baptized into Jesus Christ and confess him as Lord and Saviour are brought by the Holy Spirit into one fully committed fellowship, holding the one apostolic faith, preaching the one Gospel, joining in common prayer, and having a corporate life reaching out in witness and service to all, and at the same time are united with the whole Christian fellowship in all places and all ages in such wise that ministry and members are accepted by all, and that all can act and speak together as occasion requires for the tasks to which God calls his people. It is for such unity that we believe we must pray and work (New Delhi Statement on Unity, n. 2).

The Church of Sweden has a proud ecumenical heritage from the early $20^{\text {th }}$ century, particularly from the ecumenical pioneer Archbishop Nathan Söderblom (1866-1931). It has played a considerable role in the World Council of Churches, it was represented by an observer bishop at the Second Vatican Council, and it has been eager to receive and incorporate in its own life several of the achievements of international ecumenical theology. However, a church with the structure it has, a church so deeply involved in secular society, cannot really think of ecumenism in terms of visible unity or full ecclesiastical communion. Besides, the lack of doctrinal authority on the level of bishops and priests makes it impossible to make any kind of doctrinal agreements with this church.

All this is in the long run a serious threat to the vitality of the ecumenical movement and to ecumenical efforts. And this is a tragedy, not least when one thinks of Jesus' prayer "that they may all be one [...] so that the world may believe that you have sent me" (John 17:21). Visible unity is an absolute necessity, the perhaps most important conceivable contribution to making "the world" believe in Christ. This is also the reason 
why the recent popes have stressed that there is no way back in ecumenism; the efforts must continue, though the tangible reasons for believing in success may at times be weak.

\section{Facing the future}

Where does all this leave the Catholic church? As I hinted at earlier, it is small, and it has members from all over the globe. Many of them, and of the priests, are not yet fully immersed in Swedish society. On the other hand, the fact that the church is so multicoloured is in itself important; it means that it almost automatically gives a significant contribution to that integration of people from various backgrounds which is an increasingly important task in Swedish societal life of today. But it is a church with limited resources, and it has so far seemed necessary for it to concentrate on procuring its own members with what is the most essential: the Word, the sacraments, spiritual guidance and a certain teaching.

In the long run, however, the Catholic church in Sweden cannot avoid developing a strategy, not only for its own internal life but also for its outreach in society. This will surely require, among other things, the strengthening of catechesis of adults, in order to make lay people more capable of bearing witness to the faith. As Pope Paul VI said in Evangelii nuntiandi (1975), evangelisation is always the most important task of the church, wherever she lives:

The task of evangelising all people constitutes the essential mission of the Church. It is a task and mission which the vast and profound changes of present-day society make all the more urgent. [...] For the Church, evangelising means bringing the Good News into all the strata of humanity, and through its influence transforming humanity from within and making it new. [...] But there is no new humanity if there are not first of all new persons renewed by Baptism and by lives lived according to the Gospel. The purpose of evangelisation is therefore precisely this interior change, and if it had to be expressed in one sentence, the best way of stating it would be to say that the Church evangelises when she seeks to convert, solely through the divine power of the message she proclaims, both the personal and collective consciences of peo- 
ple, the activities in which they engage, and the lives and concrete milieu which are theirs (Evangelii nuntiandi, 1975, nn. 14 and 18, emphasis added).

Evangelii nuntiandi is still a valid program for how secularisation should be encountered, but our church is still far from having put it into practice. To do so will require sincere efforts, much thought, much prayer and sacrifices. 


\section{Summary}

\section{The Church in Sweden. Secularisation and Ecumenism as Challenges}

Sweden is one of the most secularised countries in the world. The article treats, against a historical background, two main challenges for the Christian church in the contemporary situation: secularisation as such and ecumenism. The dominant strategies of the majority church, the formerly established Lutheran church, when it comes to encountering radical secularisation are discussed, as are the difficulties in forming a common Christian vision of the situation and of common strategies for evangelisation. Much space is devoted to the so-called Folk Church ideology governing the policy of the Lutheran church. The urgent need for new ways of witnessing to the Gospel is stressed.

Keywords: Sweden, secularisation, religious freedom, Lutheran church, church and state, Folk Church

\section{Kościół w Szwecji. Sekularyzacja i ekumenizm jako zmiany}

Szwecja należy do najbardziej zsekularyzowanych krajów na świecie. W oparciu o dane historyczne artykuł ukazuje dwa najważniejsze wyzwania Kościoła w obecnej sytuacji: przeciwdziałanie sekularyzacji jako takiej i ekumenizm. Autor podejmuje dyskusję nad głównymi działaniami Kościoła, większościowego Kościoła luterańskiego wobec radykalnej sekularyzacji, utrudniającej wypracowanie jednolitej wizji chrześcijaństwa w aktualnej sytuacji oraz wspólnej strategii ewangelizacyjnej. W opracowaniu wiele miejsca poświęcono tzw. ideologii Kościoła narodowego, którą głównie kieruje się Kościół luterański. Podkreślono pilną potrzebę nowych sposobów dawania świadectwa Ewangelii.

Słowa kluczowe: Szwecja, sekularyzacja, wolność religijna, Kościół luterański, Kościół i państwo, Kościół ludowy

\section{Bibliography}

Church of Sweden statistics, http://www.svenskakyrkan.se/default.aspx?id= 1132666\&ptid=48063 (7.04.2015).

Davie G., Europe: The Exceptional Case: Parameters of Faith in the Modern World, London 2002.

Davie G., Religion in Modern Europe: A Memory Mutates, Oxford 2000.

Delumeau J., Le christianisme va-t-il mourir?, Paris 1977.

Delumeau J., Un chemin d'histoire: Chrétienté et christianisme, Paris 1981. 
Eurel: Données sociologiques et juridiques sur la religion en Europe, http://www.eurel. info/spip.php?rubrique66\&lang=fr (24.04.2015).

Rum för alla: Lite mer om Svenska kyrkan [A Room for Everybody: A Little More about the Church of Sweden], http://issuu.com/svenskakyrkan/docs/rum_f_r_alla_lite_mer_ om_svenska_/1 (21.04.2015).

Svenska kyrkan i siffror [The Church of Sweden in Figures], http://www.svenskakyr kan.se/statistik (21.04.2015).

World Values Survey (2011), http://www.worldvaluessurvey.org/WVSContents. jsp?CMSID=Findings (24.04.2015).

Zaremba M. Kyrkan \& friheten [The Church and Freedom], Gothenburg 2000. 